\title{
Effect of drying methods and pretreatments on dehydration and rehydration characteristics of osmo-dried papaya slices
}

\author{
Vikrant Kumar, Jaivir Singh, Ratnesh Kumar, Sunil, Vipul Chaudhary and Balwant Singh
}

Received : 17.01.2019; Revised : 13.02.2019; Accepted : 04.03 .2019

See end of the Paper for authors' affiliation

Correspondence to :

Vikrant Kumar

Department of Agricultural Engineering, Sardar Vallabh

Bhai Patel University of

Agriculture and Technology,

Meerut (U.P.) India

Email:vkvk6096@

gmail.com
- ABSTRACT : Papaya slices were treated with different pre-treatments namely control, $\mathbf{T}_{1}=$ Control, $\mathrm{T}_{2}=$ Potassium metabisulphate, $\mathrm{T}_{3}=$ Sodium bisulphate and $\mathrm{T}_{4}=$ Blanching at $95^{\circ} \mathrm{C}$ for 4 minute. The treated sample were osmosed in syrup solution of $55^{\circ} \mathrm{Brix}$ and $65^{\circ} \mathrm{Brix}$ for period of 180 minutes, than wiped and dried in tray dryer and hot air oven dryer at $60^{\circ} \mathrm{C}$. It was revealed from the results that, drying of papaya slices in a hot air oven dryer takes only 600 minutes for drying from an initial weight of sample to final weight of sample. The rehydration ratio was recorded of $65^{\circ} \mathrm{Brix}$ that 4.95, 2.61, 3.05 and 2.89 for $\mathrm{T}_{1}, \mathrm{~T}_{2}, \mathrm{~T}_{3}$ and $\mathrm{T}_{4}$ samples after 90 days. Drying of papaya slices in a Tray dryer takes only 660 minutes. The dehydration ratio was recorded of $65^{\circ} \mathrm{Brix}$ that $8.40,3.52$, 4.13 and 3.10 for $\mathrm{T}_{1}, \mathrm{~T}_{2}, \mathrm{~T}_{3}$ and $\mathrm{T}_{4}$ samples.

- KEY WORDS : Dehydration ratio, Rehydration ratio, Co-efficient, Osmo-dried papaya slice

- HOW TO CITE THIS PAPER : Kumar, Vikrant, Singh, Jaivir, Kumar, Ratnesh, Sunil, Chaudhary, Vipul and Singh, Balwant (2019). Effect of drying methods and pretreatments on dehydration and rehydration characteristics of osmo-dried papaya slices. Internat. J. Agric. Engg., 12(1) : 73-77, DOI: 10.15740/HAS/IJAE/12.1/73-77. Copyright@2019: Hind Agri-Horticultural Society. 